\title{
The structure and composition of the woody plant communities of Majete Wildlife Reserve, Malawi
}

\section{Authors}

${ }^{1}$ Willem A. Nieman (a) ${ }^{2}$ Brian W. van Wilgen

Alison J. Leslie

\section{Affiliations}

'Department of Conservation Ecology and Entomology, Stellenbosch University, Private Bag X1, Matieland 7602, Western Cape, South Africa

${ }^{2}$ Centre for Invasion Biology, Department of Botany and Zoology, Stellenbosch University, Stellenbosch, South Africa.

\section{Corresponding Author}

Willem A. Nieman; e-mail:wian.nieman@gmail.com

\section{Dates}

Submitted: 6 October 2020 Accepted: 21 May 2021 Published: 10 September 2021

\section{How to cite this article:}

Nieman, W.A., van Wilgen, B.W. \& Leslie, A.J., 2021, 'The structure and composition of the woody plant communities of Majete Wildlife Reserve, Malawi', Bothalia 51(2), a7. http://dx.doi. org/10.38201/btha.abc.v51.i2.7

\section{Copyright: (c) 2021. The Authors}

Licensee: SANBI. This work is licensed under the Creative Commons Attribution 4.0 International License.
Background: The role of protected areas as sanctuaries for indigenous vegetation in Malawi, particularly miombo woodlands, will become increasingly important in the face of global change and rising human populations. Accurate knowledge of the extent and composition of woody components of plant communities will therefore play a vital part in informing conservation and management initiatives.

Objectives: The aims of this study were to (1) classify, describe and map the woody plant communities of the Majete Wildlife Reserve (MWR) using a combination of remote sensing and on-the-ground surveys, and (2) to compile an inventory of the tree and shrub species present in MWR.

Methods: A combination of remote sensing and on-the-ground surveys was used to classify, describe and map the woody plant communities of MWR. Additionally, an inventory of the tree and shrub species in each delineated woody plant community was made.

Results: Five distinct woody plant communities, two of which were subdivided into three sub-communities each, were recognised in MWR, and a total of 118 woody plant species within 31 families were identified. A description of the location, structure and species composition of each community is provided. Miombo was the most widespread community (covering $35.9 \%$ of the area), while the lower-altitude shrublands and woodlands were the richest floristically.

Conclusion: This information is intended to provide a basis for improved management planning and policy development, including fire management, the placement of infrastructure, and the re-introduction of extirpated mammal species, as well as providing a baseline against which to monitor change. Additionally, this study provided an example of how the combination of remote sensing and ground surveys can provide a rapid and relatively inexpensive method for classifying the woody components of communities at a relatively fine scale over large areas, which may become particularly relevant for developing countries and regions that undergo rapid and constant change.

Keywords: fire management; miombo; remote sensing; savanna; woodland.

\section{Introduction}

Savanna ecosystems cover approximately 40\% of Africa (Scholes \& Walker 1993), and the most common variant in southern and eastern Africa, namely miombo woodland, covers approximately 2.7 million $\mathrm{km}^{2}$ in seven countries (Frost 1996; Kutsch et al. 2011). Malawi falls entirely within the Miombo Ecoregion ( 3.6 million $\mathrm{km}^{2}$; Byers 2001), and the ecoregion was identified as one of five global wilderness areas that require conservation prioritisation (Mittermeier et al. 2003). The Miombo Ecoregion is an amalgamation of several smaller ecoregions, 
with the southern section of Malawi containing the Eastern Miombo Woodlands Ecoregion (EMWE), extending from southeastern Tanzania and northern Mozambique into parts of southeastern Malawi, and the Zambezian and Mopane Woodland Ecoregion (ZMWE) in southwestern Malawi (Malaisse \& Parent 1985; Byers 2001). The EMWE is dominated by miombo sensu stricto, characterised by trees in the genus Brachystegia, occurring either alone or together with Julbernardia and Isoberlinia species (Geldenhuys \& Golding 2008). The EMWE is further subdivided into drier miombo and wetter miombo by the $1000 \mathrm{~mm}$ rainfall isohyet (White 1983; Byers 2001). The ZMWE consists mainly of broadleaf, deciduous savannas and woodlands interspersed with edaphic grasslands (White 1983; Chirwa, Syampungani \& Geldenhuys 2014). Collectively, these two ecoregions were formerly classified by Huntley (1982) as Caesalpinoid (now Detarioideae) woodland, or broadleaved dystrophic savanna woodland, while White (1983) classified the area as the Zambezian Phytoregion, with Zambezian woodland being the most widespread woody plant community in the region.

True miombo woodland constitutes $92.4 \%$ of the natural vegetation of Malawi (Government of Malawi 2010). The vast majority of extant natural vegetation is, however, confined to small, isolated areas that are subjected to rapid deforestation rates of up to $0.9 \%$ annually (FAO 2015). Additionally, while projections of future drier climates in sub-Saharan Africa suggests the range of dry miombo may expand (Jinga \& Palagi 2020), a sharp increase in the human population (Eastwood \& Lipton 2011) will place undue pressure on remaining miombo woodlands, which already support the livelihoods of more than 100 million people either directly or indirectly (Syampungani et al. 2009). The role of protected areas (PAs) as sanctuaries for miombo vegetation, as well as other woodland vegetation types, will thus become even more significant in the future, and knowledge of their composition and structure is needed as a basis for their sustainable management. Majete Wildlife Reserve (MWR) in Malawi was proclaimed in 1955 and was taken over in 2003 by African Parks with the aim of restoring, developing and preserving the integrity of all facets of the area's biodiversity. The reserve is situated in southwestern Malawi, at the intersection of the EMWE and the ZMWE (Byers 2001; Munishi, Temu \& Soka 2011), making this a unique study site to compare contrasting vegetative communities. Different plant communities may also require specific management approaches, adding to the need for an accurate vegetation description at a scale appropriate to management. Though useful, the coarse-scale classification of ecoregions fails to describe plant communities and their distributions at the scale of PAs. Classifying vegetative communities at scales finer that those of ecoregions can be extremely resource intensive and is therefore likely not realistic in most African countries. More cost-effective solutions are thus needed, and remote sensing may offer such a solution to delineate woody plant communities in Africa (Peel, Kruger \& MacFadyen 2007; van Rooyen et al. 2008). The delineation of non-woody vegetative components, which may be crucial to certain aspects of environmental management, is however likely not achievable with remote sensing approaches.

Some information on the vegetation of MWR or nearby regions can be found in unpublished theses (e.g. Olivier 2018; Sherry 1989), technical reports (e.g. Dowsett-Lemaire \& Dowsett 2002; Kabwazi et al. 2000; Nieman 2020), or peer-reviewed articles (e.g. Hall-Martin \& Drummond 1980; Nieman, van Wilgen \& Leslie 2021), but an updated and detailed description of the woody vegetation in MWR is lacking. The miombo woodlands found in MWR fall within the distribution of dry miombo (White 1983; Frost 1996), which is floristically poor compared to the much more diverse wet miombo, and is characterised by the presence of Brachystegia boehmii, B. spiciformis, and Julbernadia globiflora (Frost 1996; Kapinga et al. 2018; Moura et al. 2018). Typically, miombo woodlands are bordered by Baikiaea woodlands, Acacia (now Vachellia or Senegalia)-Combretum woodlands, mopane woodlands, or Burkea-Terminalia woodlands (Byers 2001; Chirwa, Syampungani \& Geldenhuys 2014; Maquia et al. 2019).

The aims of this study were to (1) classify, describe and map the woody plant communities of MWR using a combination of remote sensing and on-the-ground surveys, and (2) to compile an inventory of the tree and shrub species present in MWR. This information is intended to provide a basis for improved management planning and policy development, including fire management, the placement of infrastructure, and the re-introduction of extirpated mammal species, as well as providing a baseline against which to monitor change (Kremen 1992; Peel et al. 2007).

\section{Materials and methods}

\section{Study site}

Majete Wildlife Reserve (MWR) is situated in the Lower Shire Valley, part of the Great Rift Valley in the south of Malawi. The reserve covers roughly $700 \mathrm{~km}^{2}$ and is situated in a tropical climate zone. The underlying climate can be categorised into three distinct seasons (Hall-Martin 1972), namely the wet season (December to March), the cool dry season (April to August), and the hot dry season (September to November). Mean monthly temperatures range from $20.5^{\circ} \mathrm{C}$ (June and July) to $27.8^{\circ} \mathrm{C}$ (November), with maximum temperatures often reaching $\sim 45^{\circ} \mathrm{C}$. A distinct $\mathrm{N}-\mathrm{S}$ line divides MWR into the western upland area (altitude $>350$ mamsl) and the eastern lowland area (altitude $<350$ mamsl). The topography of the eastern lowlands is relatively flat with few rocky 
outcrops, with mean annual precipitation (MAP) ranging between 680-800 mm, while the western uplands consists of many rocky outcrops, and receiving slightly higher MAP (700-1 000 mm) (Hall-Martin 1972). A detailed description of the geology and soils of MWR is lacking, but most soils are shallow, stony lithosols of poor nutrient status, with fertile alluvial soil only occurring along a few river beds (Bell 1984; Sherry 1989). Two perennial rivers occur in the northeastern section of MWR, which, along with ten artificial water points and seven natural springs, provide the only source of water for animals in the dry season. The vegetation was previously described by Sherry (1989) as tropical dry deciduous woodland, miombo savanna woodland, riverine associations, and riparian thicket. Several browsing herbivore species that affect the structure of woody vegetation are present in MWR, notably elephant (Loxodonta africana), black rhinoceros (Diceros bicornis), giraffe (Giraffa camelopardalis), kudu (Tragelaphus strepsiceros) and impala (Aepyceros melampus).

\section{Data collection and analyses}

\section{Delineation of land cover types with remote sensing}

The Sentinel-2 cloudless land cover product was obtained from the Copernicus global land service (Buchhorn et al. 2019), and used to map land cover at $100 \mathrm{~m}$ spatial resolution for MWR in QGIS v3.10. The product uses supervised classification of reflectance data and provides 23 distinct land cover classes globally. Five of these (open woodlands, closed woodlands, shrublands, herbaceous vegetation, and permanent inland water bodies) were present in MWR. The classification product was in sinusoidal UTM projected at Datum WGS84 and is updated at annual time steps. The latest available iteration (2018) was used. Additionally, the ASTER digital elevation model (DEM) version 3 (ASTGTM v003) was obtained from the U.S. Geological Survey and used to create an elevation profile for MWR at a spatial resolution of 1 arc second $(\sim 30 \mathrm{~m})$. The inclusion of a DEM would likely allow for better separation of plant communities (Sedano, Gong \& Ferrão 2005). The DEM was simplified in QGIS v3.10 to display three equal interval elevation categories in MWR, and used to divide land cover classes into separate elevation categories where relevant. The lowest point in MWR is where the Mwembezi River exits the reserve (90 mamsl) in the northeast, and the highest point is at Kapirimbewe in the northwest (880 mamsl). The final land cover classes were reprojected to 5 ha grid cells for subsequent analyses.

\section{Delineation of plant communities}

Following the delineation of land cover classes with remote sensing, 195 field sites (circular plots of $50 \mathrm{~m}$ radius, covering an area that was considered adequate to encapsulate the composition of the woody plant community) were selected across all classes for the final classification of woody plant communities based on the dominant tree species. Each site was chosen to be homogenous and representative of the respective land cover classes, and the sites were surveyed during May-June 2020. The number of sites surveyed in each land cover class was proportional to its extent (area) and ranged from two to 66 per land cover class. At each of the 195 field sites, a count of the number of individual trees or shrubs belonging to eight woody genera was made. Based on their prevalence in MWR, and woody plant community classifications in other savannas (White 1983; Byers 2001; Peel et al. 2007; Gandiwa \& Kativu 2009; Munishi et al. 2011; Clegg \& Connor 2012; Maquia et al. 2019), the chosen genera incorporated the most important characteristic species for classifying woody plant communities, and were ultimately used as a basis for describing the final plant communities present in MWR. The chosen genera were: Senegalia (including S. galpinii, S. nigrescens and S. burkei), Vachellia (including V. karroo, V. nilotica and V. torrei), Brachystegia (including B. boehmii, $B$. allenii, B. longifolia, B. spiciformis and B.utilis), Julbernardia (including J. globiflora), Sclerocarya (including $S$. birrea), Terminalia (including T. mollis, T. sericea and T. stenostachya), Combretum (including C. adenogonium, C. apiculatum, C. hereroense, C. imberbe, C. molle, C. mossambicense and C. zeyheri), and Colophospermum (including C. mopane).

\section{Accuracy assessment}

Woody vegetation structural data were collected at each of the 195 field sites to assess whether the remotely sensed land cover classes were matched by vegetation physiognomy on the ground. At each field site, the physiognomy and structure of the vegetation was classed according to the broad classification of Edwards (1983) by recording the dominant primary growth form (trees or shrubs), projected crown cover classes (closed, open, sparse or scattered), and the mean number of crown diameters by which plant crowns were separated. The accuracy assessment was done by comparing the classified pixel to the same site in the field through a confusion matrix that compared the Edwards classifications to the Sentinel land cover classes. Overall map accuracy was determined by summing the number of pixels classified correctly and dividing by the number of pixels (Mohd Hasmadi, Pakhriazad \& Shahrin 2009).

\section{Plant community richness and diversity}

At 94 of the 195 field sites, a list of all tree and shrub species present was compiled by noting the species that were visible to an observer walking along a line transect 
of $50 \mathrm{~m}$. The location of the transects was chosen to be relatively evenly distributed across MWR, while still encapsulating obvious landscape variations (such as topography and riverbeds) and to ensure that all woody vegetative variations were sampled. Prior to conducting the inventories, the species-area method (Smith, Meredith \& Johns 1999) was used to determine the optimal length of transects by noting the increase in the number of species observed as the transect length increased. Transect length was deemed optimal when additional sampling did not identify a significant number of novel species. Species were identified on site where possible, but a sample was taken for later identification where uncertainty existed.

Sampling performance of species inventories made along the 94 transects was evaluated through the construction of species accumulation curves for each woody plant community and for MWR as a whole (Colwell \& Coddington 1994). Species accumulation curves also provided a reliable estimate of species richness due to the variation in sample sizes, and provided an estimate of the predicted number of species that could be found if sampling continued indefinitely based on the rate of species discovery in this study (Colwell 2005). For this purpose, the performance of six non-parametric species richness estimators appropriate for incidence-based data were used, namely the Chao 2 estimator, the bias-corrected form of the Chao 2 estimator (Chao 2-bc), a newer version of the Chao 2 estimator (iChao2), the incidence-based coverage estimator (ICE), and two Jackknife species richness estimators (Jack 1 and Jack 2) (Burnham \& Overton 1978; Chao 2005; Chiu et al. 2014). The sample order was randomised 100 times for each of the calculations to provide mean statistics at each sample order, thereby generating smooth accumulation curves (Colwell \& Coddington 1994; Nieman, Leslie \& Wilkinson 2019). Due to its relatively small extent in MWR, grasslands (Gr) were grouped with shrublands and woodlands (SW - see plant community descriptions) based on the clear similarity in geographical location and woody species similarity between these plant communities. In addition, the woody species diversity and evenness or equitability was quantified with the use of standard ecological diversity indices for MWR as a whole, as well as for each of the plant communities. Specifically, woody species diversity was expressed using the Shannon-Wiener diversity index $\left(\mathrm{H}^{\prime}\right)$, the Simpson diversity index (1-D), and inverse Simpson diversity index (1/D). In all instances, higher values equate to a higher level of diversity in the sample, and thus higher entropy and less dominance by one or a few species. Evenness was expressed with the Shannon evenness index $\left(J^{\prime}\right)$, wherein values approaching zero represent low evenness in the sample, and thus dominance by one or a few species. The coefficient of variation (CV) was used to describe the degree of heterogeneity among species incidence, where zero represents a completely homogenous sample. Finally, the Jaccard coefficient was used to determine similarity between the species' assemblages compiled for each plant community, and a dendrogram was constructed using the k-means clustering algorithm with Euclidian distances. All species richness estimator and index values were calculated in R v4.0.1.

\section{Results}

\section{Woody plant communities recognised}

The final classification of the land cover of MWR was done at $90.77 \%$ accuracy (i.e. $90.77 \%$ of pixels from the Sentinel map matched the corresponding woody plant community structure on the ground), and included five woody plant communities, two of which were further subdivided into three sub-communities each (Table 1). The extent and distribution of these plant communities and sub-communities were subsequently mapped at the scale of the individual 5 ha pixels (Figure 3). At the level of the individual plant communities and sub-communities, a clear distinction in terms of woody species assemblages was confirmed by the Jaccard similarity index (Figure 1). The floristic composition of riparian woodland was the least similar to all other woody plant communities, while grassland was closely related to the shrubland and woodland sub-types. The floristic composition of all miombo sub-types were also closely related.

\section{Plant community descriptions}

\section{Riparian woodland}

Riparian woodland (Rw) (Figure 2A) occurred on alluvium fringing the only two perennial rivers in MWR, namely the Mkulumadzi and Shire rivers. The rivers respectively form $9 \mathrm{~km}$ and $7 \mathrm{~km}$ of the outer reserve boundary in the northeastern section of the reserve. As expected (Smith, Meredith \& Johns 1999), this plant community was characterised by a distinct species composition and density compared to the rest of MWR, but unlike the other plant communities, was not characterised by one or a few dominant genera or species. The species recorded most frequently ( $\geq 40 \%$ ) were Philenoptera violacea, Allophylus africanus, Senegalia nigrescens, Terminalia sericea, Sclerocarya birrea, Cleistochlamys kirkii, Kigelia africana, Combretum imberbe, Pterocarpus rotundifolius, Cremaspora triflora, Gymnosporia senegalensis, Diospyros squarrosa, Croton megalobotrys and Grewia flavescens (Table 2). This woody plant community was made up by 52 pixels, thus covering 245.1 ha, or $0.34 \%$ of MWR. Tree cover 
Table 1. The extent of woody plant communities and sub-communities in Majete Wildlife Reserve, and an assessment of the extent of agreement between remotely sensed land cover types and assessments of vegetation structure in ground surveys

\begin{tabular}{lcccc}
\hline Plant community & $\begin{array}{c}\text { Number of } \\
\mathbf{5} \text { ha pixels }\end{array}$ & $\begin{array}{c}\text { Area occupied } \\
\text { (ha) }\end{array}$ & $\begin{array}{c}\text { Number of } \\
\text { sampling sites }\end{array}$ & $\begin{array}{c}\text { Extent of agreement between } \\
\text { satellite and ground } \\
\text { classification (\%) }\end{array}$ \\
\hline Riparian woodland (Rw) & 52 & 245.1 & 15 & 100.00 \\
\hline Grassland (Gr) & 47 & 221.6 & 2 & 100.00 \\
\hline Shrublands and woodlands (SW) & 3912 & 19855.4 & 59 & 86.44 \\
\hline Shrubland (SW1) & 250 & 2592.7 & 87.50 \\
\hline Open woodland (SW2) & 3226 & 15207.4 & 42 & 90.48 \\
\hline Closed woodland (SW3) & 436 & 2055.3 & 96.67 \\
\hline Transitional woodland (Tw) & 5392 & 25417.9 & 53 & 100.00 \\
\hline Miombo (M) & 5446 & 25672.4 & 66 & 84.85 \\
\hline Open miombo (M1) & 1073 & 5058.1 & 11 & 100.00 \\
\hline Low-altitude, closed miombo (M2) & 2385 & 11242.9 & 24 & 83.33 \\
\hline High-altitude, closed miombo (M3) & 1988 & 9371.4 & 31 & 80.65 \\
\hline Total & $\mathbf{1 4 ~ 8 4 9}$ & $\mathbf{7 1 4 1 2 . 4}$ & $\mathbf{1 9 5}$ & $\mathbf{9 0 . 7 7}$ \\
\hline
\end{tabular}

was typically between 10 and $75 \%$, and tree height often exceeded $15 \mathrm{~m}$. The woody plant community occurred at low elevation $(<250$ mamsl), and contained very little grass cover, while bare ground patches and forbs were prominent.

\section{Grassland}

Grassland (Gr) (Figure 2B) was found in a few scattered locations in the low-altitude $(<250$ mamsl) belt of the MWR, and its presence was thus not significant, as it only covered $221.6 \mathrm{ha}$, or $0.31 \%$ of MWR. The factors determining the occurrence and distribution of grasslands are not known, but likely pertain to edaphic factors. Additionally, the location of most grassland sites on the boundary of MWR suggests that these areas may have been illegally logged and cultivated by local communities prior to the erection of the reserve fence in 2004. Grasslands in MWR may thus represent a state of secondary vegetation succession, and it is possible that they may eventually revert back to shrubland and woodland states if left undisturbed. The dominant tree and shrub species were similar to those reported in shrublands and woodlands (SW), but woody species were mostly absent or their growth was stunted. Both tree and shrub cover were less than $0.1 \%$, while grass height mainly exceeded $1 \mathrm{~m}$, and grass cover was between 10 and $100 \%$. Additionally, grassland sites were

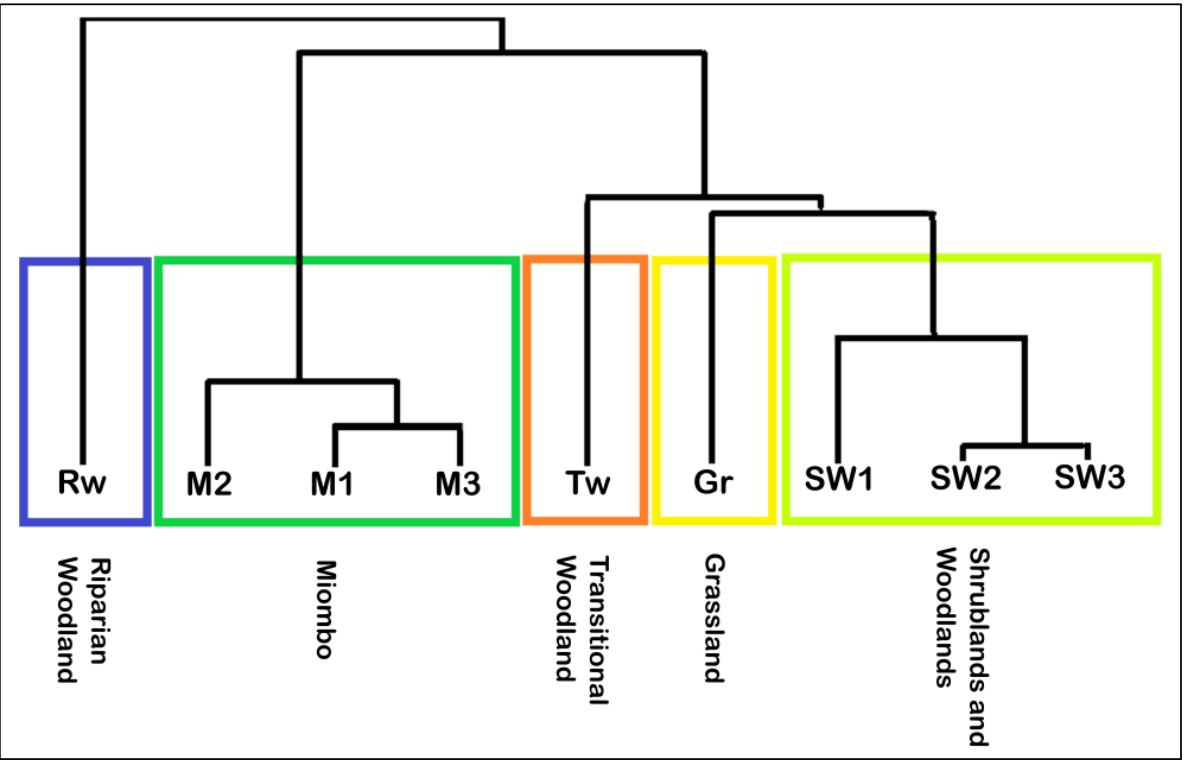

Figure 1. Dendrogram of species composition for different woody plant communities based on the Jaccard similarity index. 

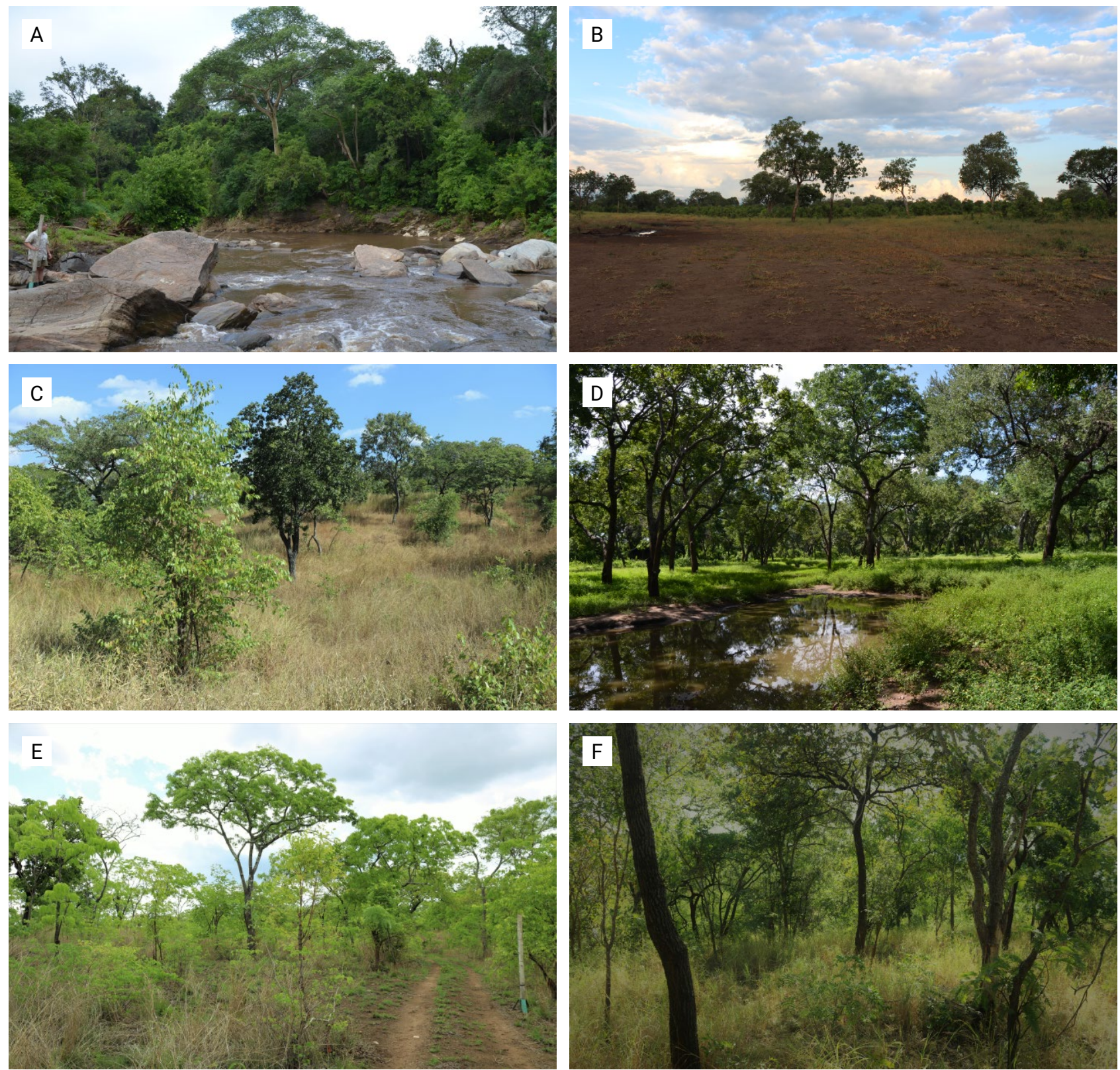

Figure 2. Typical examples of the plant communities in Majete Wildlife Reserve; A, riparian woodland (Rw); B, grassland (Gr); C-D, shrublands and woodlands (SW); E, transitional woodland (TW); and F, miombo (M). Photo credits: W.A. Nieman.

often accompanied by large expanses of bare ground, and are thus presumably exposed to higher erosion risk due to decreased soil stabilisation.

\section{Shrublands and woodlands}

Shrublands and woodlands (SW) (Figure 2C-D) covered the largest portion of the low-altitudinal $(<250$ mamsl) band in the east of MWR, and extended into some of the medium-altitude (250-450 mamsl) areas. This woody plant community was floristically rich and characterised by species in the genera Combretum, Terminalia, Vachellia, Senegalia and Sclerocarya. The most frequently recorded species ( $\geq 40 \%$ ) were Combretum adenogonium, Senegalia nigrescens, Combretum imberbe, Diospyros mespiliformis, Terminalia sericea and
Sclerocarya birrea (Table 2). Miombo dominants such as Brachystegia and Julbernardia are extremely gregarious, and rarely occur in other woody plant communities (Geldenhuys \& Golding 2008). The shrublands and woodlands in MWR were thus distinguished by the absence of typical miombo species rather than by the presence of other species (White 1983). The woody plant community was further subdivided into three sub-communities on the basis of tree and shrub cover and height that were intermixed with each other, namely shrubland (SW1), open woodland (SW2) and closed woodland (SW3).

Open woodland (SW2) was the most widespread and prevalent of the three sub-communities, covering 15207.4 ha, or $21.30 \%$, of MWR. The sub-community 


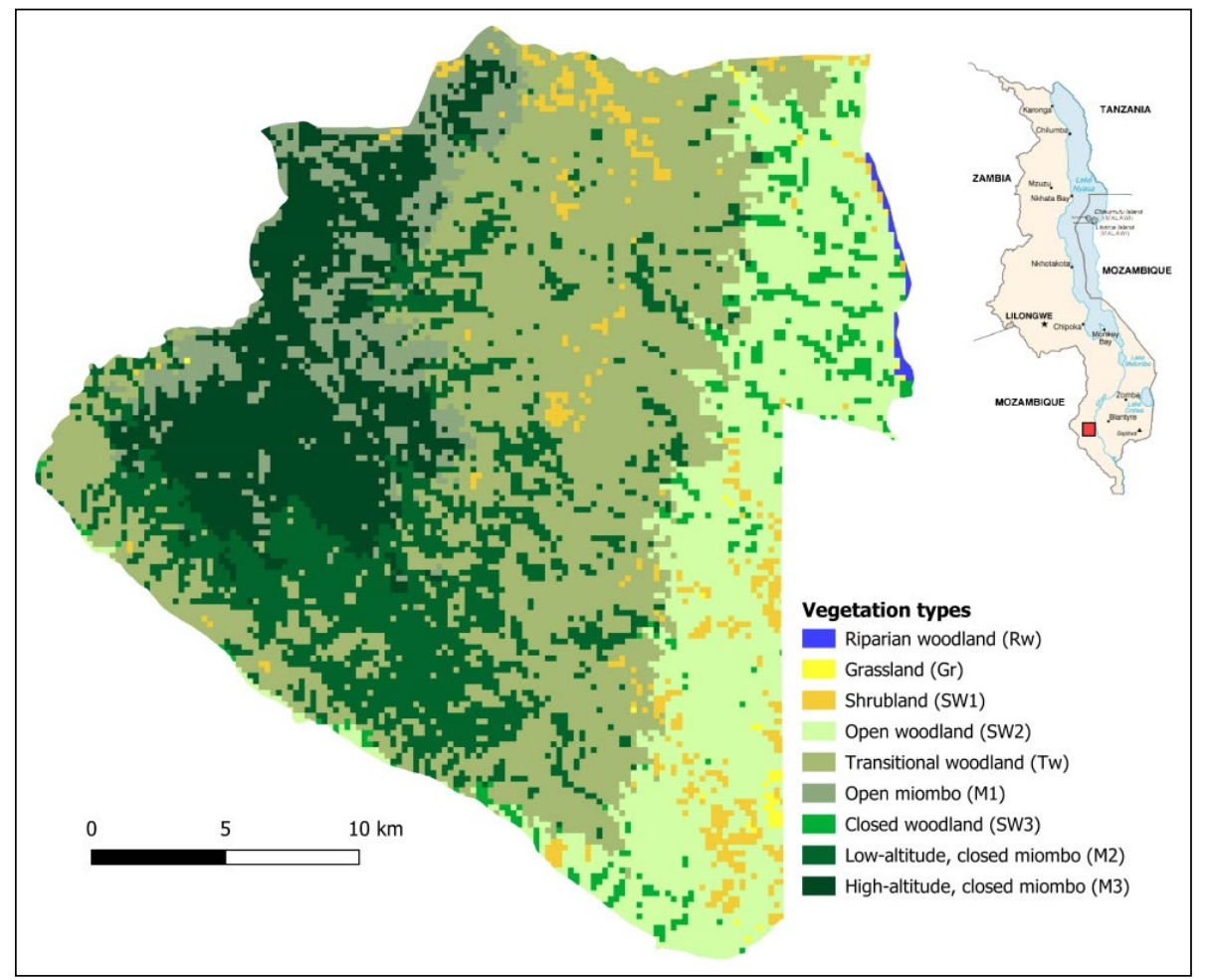

Figure 3. Distribution of woody plant communities in Majete Wildlife Reserve (MWR). The inset shows the location of the MWR in Malawi. was differentiated by its open canopy, with tree cover ranging between 1 and 10\%. Closed woodland (SW3) was much less widespread, and confined to small, isolated patches covering 2055.3 ha, or $2.88 \%$ of MWR. The sub-community was differentiated by its closed canopy, with tree cover ranging between 10 and $75 \%$. In both SW2 and SW3, tree height was generally greater than $10 \mathrm{~m}$, and shrubs higher than $1 \mathrm{~m}$ in height covered less than $10 \%$ of the total area. Shrubland (SW1) was widely dispersed, but covered only 2592.7 ha, or $3.63 \%$ of MWR. It was dominated by shrubs of $2-5 \mathrm{~m}$ in height, and stunted trees. Total tree cover was below $1 \%$, while total shrub cover ranged between 10 and $100 \%$. It is unclear why the woody component in these areas is stunted, although either short fire return intervals, high fire intensity or high herbivory pressure (particularly high elephant densities), or a combination of these, may have played a role (Trollope, 1998; Shannon et al. 2011).

\section{Transitional woodland}

Transitional woodland (Tw) (Figure 2E) was the second most widespread plant community in MWR, and existed as a transitional state between shrublands and woodlands (SW), and miombo (M) at lower and higher elevations respectively. The dominant genera thus comprised of a mixture of the genera found in the neighbouring plant communities, as well as interspersed patches of Colophospermum mopane, and included predominantly Combretum, Terminalia, Senegalia, Colophospermum and Brachystegia. The most frequently recorded species ( $\geq 40 \%$ ) were Combretum adenogonium, Diospyros mespiliformis, Diplorhynchus condylocarpon, Combretum hereroense, Colophospermum mopane and Terminalia sericea, while miombo species (e.g. Brachystegia longifolia and B. utilis) were also commonly recorded (Table 2). The area occupied 5392 pixels, thus covering 25417.9 ha, or 35.59\% of MWR. The plant community occurred at medium-altitude (250-450 mamsl). Tree cover ranged from 1 to $10 \%$, and trees were generally higher than $10 \mathrm{~m}$. Shrubs higher than $1 \mathrm{~m}$ covered less than $10 \%$ of the total area. The isolated pockets of mopane woodlands were dominated by small $(<5 \mathrm{~m})$ Colophospermum mopane shrubs, either alone or together with Senegalia nigrescens, Vachellia nilotica, Cassia abbreviata, Dalbergia melanoxylon, Pterocarpus lucens, Pterocarpus rotundifolius and Xeroderris stuhlmannii. The extent of these patches was however too small to be included as a significant and separate woody plant community in the MWR.

\section{Miombo}

Miombo woodlands (M) (Figure 2F) covered the largest area of MWR (35.9\%), and were located at high altitudes (> 250 mamsl, but mostly $>450$ mamsl) in the western upland escarpment, where steep slopes and high rock cover predominated. This thus substantiated the notion that slope and elevation are important determinants of miombo plant community patterns (Munishi, Temu \& Soka 2011). As expected of typical miombo ecosystems, the miombo plant community was dominated by trees in the legume sub-family Detarioideae (formerly Caesalpinoideae), and the genera 
Brachystegia and Julbernardia. The widespread presence of Brachystegia boehmii, Brachystegia spiciformis, and to a lesser extent, Julbernardia globiflora (Table 2), coupled with typical MAP $<1000 \mathrm{~mm}$, placed the MWR's miombo woody plant communities in the dry miombo category (White 1983; Frost 1996; Kapinga et al. 2018; Moura et al. 2018). Additionally, characteristic species of wet miombo (e.g. Brachystegia floribunda, B. glaberrima, B. taxifolia and B. wangermeeana) (White 1983) were absent from MWR. Other commonly occurring species found in miombo in this study were
Pseudolachnostylis maprouneifolia and Diplorhynchus condylocarpon, as previously found by Ribeiro et al. (2008) in northern Mozambique. A well-developed grass layer was also present throughout. The miombo woodland community was further subdivided into three sub-communities based on altitude and canopy cover, namely open miombo (M1), low-altitude, closed miombo (M2), and high-altitude, closed miombo (M3). In all three sub-communities, trees were generally taller than $10 \mathrm{~m}$, and shrubs above $1 \mathrm{~m}$ in height covered less than $10 \%$ of the total area.

Table 2. Dominant species associated with four woody plant communities in Majete Wildlife Reserve. Species were included if they occupied $>40 \%$ of all sites surveyed (indicated by ' $\mathrm{X}^{\prime}$ ) or if they were found in one plant community only [indicated by ${ }^{\prime * \prime}$, note that species only encountered once in the survey (singletons) are not included]

\begin{tabular}{|c|c|c|c|c|}
\hline \multirow[t]{2}{*}{ Species } & \multicolumn{4}{|c|}{ Woody plant community } \\
\hline & Riparian woodland & $\begin{array}{l}\text { Shrublands and } \\
\text { woodlands }\end{array}$ & Transitional woodlands & Miombo \\
\hline Dalbergia arbutifolia & * & & & \\
\hline Ficus sycamorus & $*$ & & & \\
\hline Friesodielsia obovata & $*$ & & & \\
\hline Philenoptera violacea & $x$ & & & \\
\hline Allophylus africanus & $x$ & & & \\
\hline Cleistochlamys kirkii & $x$ & & & \\
\hline Pterocarpus rotundifolius & $x$ & & & \\
\hline Kigelia africana & $x$ & & & \\
\hline Cremaspora trifolia & $x$ & & & \\
\hline Gymnosporia senegalensis & $x$ & & & \\
\hline Diospyros squarrosa & $x$ & & & \\
\hline Croton megalobotrys & $x$ & & & \\
\hline Grewia flavescens & $x$ & & & \\
\hline Senegalia nigresens & $x$ & $x$ & & \\
\hline Allophylus africanus & $x$ & $x$ & & \\
\hline Combretum imberbe & $x$ & $x$ & & \\
\hline Sclerocarya birrea & $x$ & $x$ & & \\
\hline Terminalia sericea & $x$ & $x$ & $x$ & \\
\hline Hyphaene petersiana & & $*$ & & \\
\hline Kirkia acuminata & & $*$ & & \\
\hline Combretum adenogonium & & $x$ & $x$ & \\
\hline Diospyros mespiliformis & & $x$ & $x$ & \\
\hline Combretum heteroense & & & $x$ & \\
\hline Colophospermum mopane & & & $x$ & \\
\hline Diplorhynchus condylocarpon & & & $x$ & $x$ \\
\hline Brachystegia longifolia & & & & $x$ \\
\hline Brachystegia utilis & & & & $x$ \\
\hline Julbernadia globiflora & & & & $*$ \\
\hline
\end{tabular}


Open miombo (M1) was characterised by low tree cover (1-10\%), and occupied 5058.1 ha, or $7.08 \%$ of MWR. It occurred only at elevations greater than 450 mamsl in the western uplands of MWR, and mainly on the fringes of the denser, closed-canopy miombo woodlands. The most frequently recorded species were Brachystegia longifolia, Julbernardia globiflora, B. utilis and Diplorhynchus condylocarpon. Low-altitude, closed miombo (M2) occurred at elevations between 250 and 450 mamsl in the southwestern regions of the MWR, but smaller patches were also interspersed with transitional woodland. This sub-community covered 11242.9 ha, or $15.74 \%$ of MWR. Tree cover ranged between 10 and $75 \%$. The most frequently recorded species were Brachystegia longifolia, Diplorhynchus condylocarpon, B. utilis, Diospyros mespiliformis, Colophospermum mopane, Combretum adenogonium and Pseudolachnostylis maprouneifolia. High-altitude, closed miombo (M3) occurred at elevations above 450 mamsl in the western uplands of MWR, where it covered 9371.4 ha, or $13.12 \%$ of MWR. Tree cover ranged between 10 and $75 \%$, and trees between 20 and $30 \mathrm{~m}$ in height were present in a few areas. The most frequently recorded species were Brachystegia longifolia, Julbernadia globiflora, B. utilis and B. boehmii, while the associate species Diplorhynchus condylocarpon, Erythrophleum africanum, Diospyros mespiliformis, Combretum adenogonium, Pseudolachnostylis maprouneifolia and Diospyros kirkii were also abundant.

\section{Woody species diversity}

A total of 868 individuals of 118 woody plant species were identified along 94 transects in MWR, representing 16 orders and 31 families (Supplementary Material). The most species belonged to the families Fabaceae (37 species), Combretaceae (10 species), Phyllanthaceae (8 species) and Malvaceae (7 species). Together, these four families contributed more than half $(52.5 \%)$ of all species recorded. Most species were recorded infrequently, with 29 species recorded only once, and a further 17 species only recorded twice.

The species accumulation curves for MWR (Figure 4) clearly indicated that the expected number of species had reached an asymptote, suggesting that sampling size was sufficient, and that an adequate proportion of the total woody species present in MWR were identified in our survey (Begossi 1996). In contrast, none of the individual woody plant communities ever reached an asymptote. However, given the rapid initial rates of discovery, the relatively large study area, and the high species richness present in all woody plant communities, it is unlikely that a true asymptote will ever be reached without excessive sampling (Williams, Witkowski \& Balkwill 2007).

Shrublands and woodlands consistently had the highest level of diversity in terms of woody plants, while

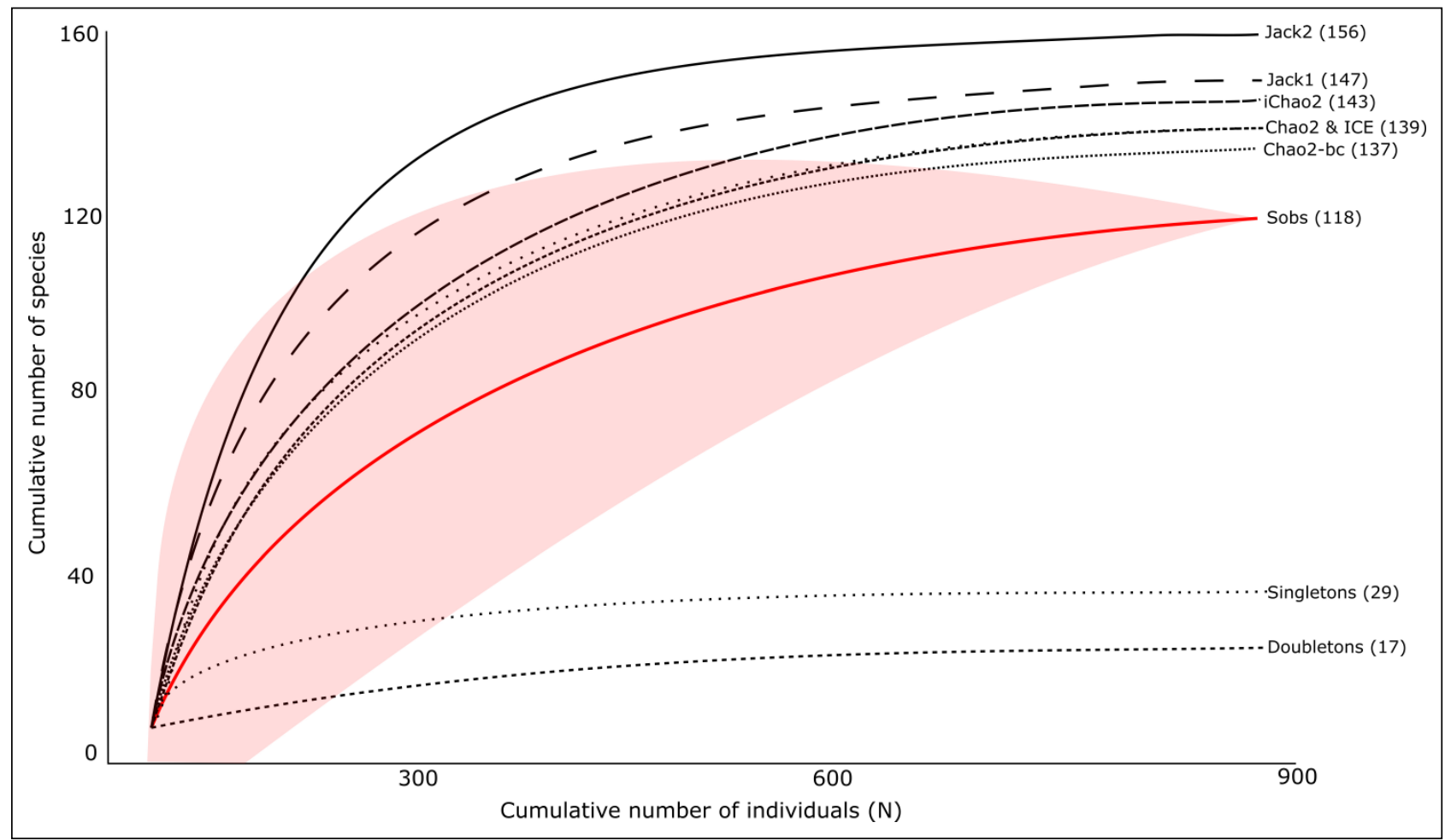

Figure 4. The comparative performance of six incidence-based species richness estimators (Chao 2, Chao 2-bc, iChao 2, Jack 1, Jack 2 and ICE) for all woody plant species recorded in Majete Wildlife Reserve $(n=118)$. The observed species accumulation curve (Sobs) with $95 \%$ confidence intervals, as well as the cumulative number of singletons (the number of species recorded only once during the survey) and doubletons (the number of species recorded only twice during the survey), were also plotted. Estimated woody species richness values are indicated in brackets. 
riparian-, miombo- and transitional woodlands had comparatively lower diversity. Shannon-Wiener diversity $\left(\mathrm{H}^{\prime}\right)$ values ranged between $3.80 \pm 0.50$ (riparian woodland) and $4.02 \pm 0.05$ (shrublands and woodlands), while Simpson diversity values $(1-\lambda)$ all ranged between 0.96 and 0.98 , with the exception of riparian woodland (0.83). Evenness values were highest for miombo and riparian woodland $\mathrm{J}^{\prime}=2.40$ and 2.34, respectively), and comparatively lower for transitional woodlands, and shrubland and woodlands $\left(J^{\prime}=2.15\right.$ and 2.12, respectively). Overall evenness in all samples was low $\left(J^{\prime}=2.04\right)$. The species richness estimates and selected ecological diversity index values can be found in Table 3.

\section{Discussion}

\section{The plant communities of Majete Wildlife Reserve}

Five distinct woody plant communities, along with six sub-communities, were identified and classified in this study (Table 1; Figure 3) based on their altitudinal and geographical location, vegetation physiognomy and structure, and woody plant species composition. Geographically, all of the woody plant communities can be broadly placed in the Miombo Ecoregion (Byers 2001), while floristically, all would fall within the Zambezian Phytoregion (White 1983; Byers 2001; Goyder et al. 2018). At the level of the entire MWR, it is clear from the species richness estimators that further sampling would not yield a significant number of novel, unrecorded tree or shrub species. However, at the level of individual plant communities, it was evident that further sampling could result in a far more complete species list. Similarly, the species richness estimators predicted that between 76 and $86 \%$ of all woody species in the MWR were recorded in our survey, which is regarded as adequate (Heck Jr, van Belle \& Simberloff 1975). However, at the individual plant community level, it was predicted that up to 75 more woody species in addition to the 44 recorded, could be found in miombo alone. This is likely due to the comparatively low sampling intensity in miombo, as a result of difficulty in accessing the area.

Mwase et al. (2007) and Missanjo et al. (2014) found 48 and 22 tree and shrub species in Malawian miombo

Table 3. Species richness estimates and selected measures of diversity calculated for woody tree and shrubs species recorded in four vegetation groupings, as well for Majete Wildlife Reserve as a whole

\begin{tabular}{|c|c|c|c|c|c|c|}
\hline \multicolumn{2}{|l|}{ Index/measure } & $\begin{array}{l}\text { Riparian } \\
\text { woodland }\end{array}$ & $\begin{array}{l}\text { Shrublands and } \\
\text { woodlands }\end{array}$ & $\begin{array}{l}\text { Transitional } \\
\text { woodland }\end{array}$ & Miombo & $\begin{array}{l}\text { Majete Wildlife } \\
\text { Reserve }\end{array}$ \\
\hline \multicolumn{2}{|l|}{ Samples (n) } & 8 & 42 & 27 & 17 & 94 \\
\hline \multicolumn{2}{|l|}{ Individuals (N) } & 114 & 408 & 248 & 98 & 868 \\
\hline \multicolumn{2}{|c|}{ Coefficient of variation (CV) } & 1.12 & 1.22 & 1.06 & 1.14 & 1.34 \\
\hline \multicolumn{2}{|c|}{ Species richness $\left(\mathrm{S}_{\mathrm{Obs}}\right)$} & 42 & 95 & 65 & 44 & 118 \\
\hline \multicolumn{2}{|c|}{ Shannon-Wiener index $\left(\mathrm{H}^{\prime}\right)$} & $3.80 \pm 0.50$ & $4.20 \pm 0.05$ & $3.90 \pm 0.08$ & $3.94 \pm 0.17$ & $4.22 \pm 0.03$ \\
\hline \multicolumn{2}{|c|}{ Simpson's index $(1-\lambda)$} & $0.83 \pm 0.00$ & $0.97 \pm 0.00$ & $0.97 \pm 0.00$ & $0.96 \pm 0.00$ & $0.98 \pm 0.00$ \\
\hline \multicolumn{2}{|c|}{ Simpson's inverse $(1 / \lambda)$} & $36.71 \pm 1.74$ & $38.60 \pm 2.14$ & $30.69 \pm 1.73$ & $22.65 \pm 2.20$ & $41.99 \pm 1.62$ \\
\hline \multicolumn{2}{|l|}{$\mathrm{H}_{\max }^{\prime}=\ln (\mathrm{S})$} & 1.62 & 2.00 & 1.81 & 1.64 & 2.07 \\
\hline \multicolumn{2}{|c|}{ Shannon $\mathrm{J}^{\prime}=\left(\mathrm{H}^{\prime} / \mathrm{H}_{\max }^{\prime}\right)$} & 2.34 & 2.12 & 2.15 & 2.40 & 2.04 \\
\hline \multicolumn{2}{|l|}{ Singletons ${ }^{1}$} & 7 & 36 & 25 & 28 & 29 \\
\hline \multicolumn{2}{|l|}{ Doubletons ${ }^{2}$} & 21 & 19 & 17 & 5 & 17 \\
\hline \multirow{6}{*}{ 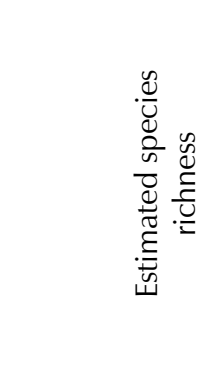 } & ICE & $110.23 \pm 25.16$ & $137.57 \pm 14.71$ & $117.70 \pm 24.70$ & $101.33 \pm 29.14$ & $138.71 \pm 8.10$ \\
\hline & Chao 2 & $111.36 \pm 36.23$ & $128.29 \pm 14.66$ & $82.70 \pm 9.28$ & $104.56 \pm 42.16$ & $138.78 \pm 11.00$ \\
\hline & Chao2-bc & $98.40 \pm 28.69$ & $125.75 \pm 13.55$ & $81.05 \pm 8.52$ & $90.70 \pm 31.30$ & $137.11 \pm 9.37$ \\
\hline & iChao2 & $115.10 \pm 38.18$ & $135.71 \pm 9.28$ & $83.74 \pm 5.86$ & $109.12 \pm 36.19$ & $142.98 \pm 6.53$ \\
\hline & Jack 1 & $67.26 \pm 5.95$ & $130.14 \pm 8.33$ & $89.07 \pm 6.87$ & $59.20 \pm 6.92$ & $146.67 \pm 7.55$ \\
\hline & Jack 2 & $87.00 \pm 11.22$ & $146.78 \pm 14.22$ & $97.09 \pm 11.61$ & $78.04 \pm 11.29$ & $155.69 \pm 12.98$ \\
\hline
\end{tabular}

${ }^{1}$ Number of species occurring only once across all samples

${ }^{2}$ Number of species occurring only twice across all samples 
ecosystems respectively, on plots $\leq 6.5$ ha in size. Further sampling of the miombo community in MWR will thus likely be needed to provide a complete list of species present in MWR. Similarly, the riparian woodlands were slightly underrepresented in this study, and many more species are predicted to occur in this woody plant community. However, given the limited extent of riparian woodlands in MWR, it is unlikely that more sampling could occur without introducing spatial autocorrelation biases, and further sampling would thus have to occur outside the reserve perimeter. The reserve is also dominated by a vast network of seasonal streambeds that become active in the rainy season (December-March), and it is possible that sampling of these streambeds could reveal similar floristic compositions to those found along perennial rivers in this study. However, despite the apparent incompleteness of the species inventory, the genera used to differentiate plant communities (Combretum, Senegalia, Terminalia, Sclerocarya, Brachystegia, Julbernardia, Colophospermum and Vachellia) were all easily and frequently recorded. The failure to detect a potentially large number of species does therefore not affect the plant community classifications produced in this study. In fact, with the exception of the genus Julbernardia, and the addition of the genera Diplorhynchus and Diospyros, these were the most abundant genera recorded in MWR. All quadrats were thus dominated by a particular combination of these genera.

\section{Remote sensing as an aid to vegetation surveys}

Producing vegetation maps for large areas from groundbased measurements is extremely resource-intensive, and their accuracy would likely be compromised in the absence of intensive surveys. Remote sensing provides a relatively inexpensive and efficient way to overcome this logistical barrier through relatively fine-scale land cover classifications over a large area. In this study, remote sensing also allowed for the accurate placement of sampling plots that were used to add detail for the completion of the vegetation survey. Despite the overall congruence between remotely sensed and groundsurveyed information in this study, as determined by the accuracy assessment, remote sensing should be accompanied by ground-truthing methods in future studies, and in many instances (especially for fine-scale vegetation mapping), more than simple ground-truthing may be necessary (Smith, Meredith \& Johns 1999). Remote sensing on its own also lacks the fine detail obtained from ground-based surveys, further substantiating the need for integrating both approaches to achieve optimal vegetation classifications (Kerr \& Ostrovsky 2003; Clegg \& Connor 2012). The combination of remote sensing and ground surveys was previously shown to be a successful method for delineating plant communities in southern Africa (Peel et al. 2007; van Rooyen et al.
2008) and elsewhere (Smith, Meredith \& Johns 1999; Satyanarayana et al. 2011).

Because detailed information on the distribution and extent of ecosystems, and contractions or expansions of land-types, will become increasingly important in the face of global change (Jinga \& Palagi 2020), the importance of rapid classification tools such as remote sensing will likely increase. Additionally, the relatively low cost of woody vegetation classifications through remote sensing, even when combined with field surveys, offers an attractive application for protected and near-natural areas in developing countries, as well as in regions that undergo rapid and constant change. Future management and conservation initiatives will thus likely rely on similar methods as those used in this study to identify and describe habitats or species that require prioritised attention. Some limitations of the method can however be expected in heavily degraded or non-natural areas, such as where natural areas have been converted for agricultural use. In these areas, poor resolution and misclassifications of remote sensing products may have a large impact on vegetation mapping and classification, and land cover classes alone will likely not be sufficient.

\section{Implications for fire management}

Most savanna trees are morphologically and physiologically adapted to persist in the presence of regular fires (Duvane et al. 2017), but fire effects may vary substantially depending on the frequency, intensity and season of the burn, as well as on woodland type (Smit et al. 2010) and interactions with other processes such as herbivory (Shannon et al. 2011). Woody vegetation maps thus provide a useful tool to plan fire management according to the distribution of dominant tree species. However, elements of fire regimes are also closely connected to non-woody components of vegetation, and information on non-woody vegetation structure and composition can thus improve approaches to fire management significantly (Nieman 2020).

In this study, the two dominant and contrasting woody plant communities, namely shrublands and woodlands, and miombo woodlands, differed substantially in terms of species composition and density, and the approaches to fire management in these areas may have to be adjusted accordingly (Nieman et al. 2021). The dominant genera of shrublands and woodlands are typically more tolerant of repeated fires of high-intensity than their miombo counterparts. In particular, Vachellia species display enhanced coppicing abilities, and fire is thus rarely able to prevent establishment and recovery, even after substantial damage to tree canopies and large-scale die-back are caused (Russell, Tedder \& Demmer 2019), and even in drier systems where the effects of fire are more pronounced (van der Merwe et al. 2019). Similarly, fire has been found not to affect 
germination rates of Senegalia species (Walters, Midgley \& Somers 2004), and Sclerocarya birrea was shown to be highly tolerant to fire (Luoga et al. 2004). For this reason, reversing undesirable woody encroachment in shrublands and woodlands would require the repeated application of high-intensity fires (Walters et al. 2004), which has been shown to be effective in reducing tree and shrub densities in Combretum, Senegalia and Sclerocarya woodlands (Sweet 1982; Enslin et al. 2000), as well as reduce tree heights and basal areas (Trapnell 1959; Shackleton \& Scholes 2000; Nefabas \& Gambiza 2007; Gandiwa \& Kativu 2009), and hamper seedling establishment and growth (Jacobs \& Biggs 2001). Ultimately, this may lead to the formation of extensively coppiced shrublands (or in extreme circumstances over a prolonged period, grasslands) (Mapaure 2001), by continually preventing trees from growing out of the fire trap and developing into tall adults (Bond \& van Wilgen 1996), as seen in nearly 3000 ha of MWR.

Increased fire frequency has also been shown to promote tree and shrub density in mopane woodlands (Gandiwa \& Kativu 2009), and to increase the number of stems on individual plants (Jacobs \& Biggs 2001; Kennedy \& Potgieter 2001). In areas of MWR where the goal is to increase the incidence of taller, closed vegetation, fire should thus be excluded for a sufficient period, or applied as low-intensity burns in the wet or early dry season (Enslin et al. 2000; Kennedy \& Potgieter 2001). Finally, Brachystegia-Julbernadia tree species have been extensively shown to be unable to adequately recover following annual or even biennial burns, and particularly from high-intensity fires in the late dry season (Thomson 1975; Ryan \& Williams 2011), resulting in the conversion of miombo woodland to a grassland state (Furley et al. 2008). In contrast, the complete absence of fire may allow miombo woodland to develop into a closed canopy forest (Trapnell 1959). Fires in the miombo woodlands of MWR should therefore be limited to the early dry season, and on a rotation of at least two years (Nieman et al. 2021).

Additionally, riparian woodlands are arguably the most important woody plant community for ensuring the survival of large mammals due to their proximity to water, and provision of shade and highly palatable vegetation (Anderson \& Walker 1974; Conybeare 2004), making appropriate conservation essential. Riparian woodlands do not burn frequently, and tend to persist in the absence of fire (van Wilgen et al. 2014), so that prescribed burning is not necessary. However, the only invasive alien plant species recorded in this study (i.e. Lantana camara and Eucalyptus camaldulensis) were found in or near the riparian woodland plant community. Presumably, the river systems act as a pathway for propagule transport originating outside MWR. These species may have the potential to facilitate fire spread (Dew et al. 2017), and fire has previously been applied by management to control $L$. camara spread in MWR (Nieman et al. 2021). Although not excessively encroached in the reserve at the time of the study, these invasive species pose a potential threat to the indigenous vegetation and should be removed.

\section{Conclusions}

The process of compiling information for the classification and identification of woody plant communities for MWR in this study was achieved at a relatively low cost and during a short time, thus providing an accurate and efficient method to elucidate fine-scale vegetation patterns in an area where little prior information existed. The short duration of the survey in a single season may translate to an underrepresented species inventory, and future studies may therefore benefit from identifying species in a variety of seasons. For example, a number of species identified by Sherry (1989) were not found in this study, including Vachellia tortilis, Breonadia microcephala, Sterculia appendiculata, Pterocarpus angolensis and Strychnos madagascariensis. Furthermore, though edaphic factors were not assessed, they are likely an important determinant of plant distributions. For example, miombo is typically found on freely drained (leached), acidic soils with a restricted rooting environment (White 1983; Jinga \& Palagi 2020), typical of the western uplands of MWR. For this reason, and many other related to environmental understanding and management, a detailed description of the geology and soils of MWR is required. Nevertheless, the woody vegetation classification and mapping of MWR achieved in this study is comprehensive, and more than adequate to effectively guide management decision-making on a variety of environmental topics, as well as policy development and species- or habitat- conservation strategies. The spatial boundaries of woody plant communities produced in this study are predominantly determined by factors that only change over geological time (e.g. slope, elevation and soils), and should therefore remain unchanged in the long-term. In contrast, the sub-type vegetation classifications (as well as grasslands), based predominantly on vegetation composition, physiognomy and structure, may be temporally altered through the effects of, among others, elephants and fire, and will therefore need to be updated periodically.

\section{Acknowledgements}

This work was supported by the Earthwatch Institute under the Majete Wildlife Research Programme, Malawi, Grant to AJI, the DSI-NRF Centre for Invasion Biology, Stellenbosch University, and the National Research Foundation of South Africa [grant number 109467 to BWvW]. WAN acknowledges logistical support received from African Parks Ltd. 


\section{Competing interests}

The authors declare that they have no financial or personal relationship(s) that may have inappropriately influenced them in writing this article.

\section{Author's contributions}

WAN sourced the data, conducted the analyses, and cowrote the paper with BWvW. AJL provided editorial input. All authors read and approved the final manuscript

\section{Reference}

Anderson, G.D. \& Walker, B.H., 1974, 'Vegetation composition and elephant damage in the Sengwa Wildlife Research Area, Rhodesia', South African Journal of Wildlife Research, 4(1), 1-14.

Begossi, A., 1996, 'Use of ecological methods in ethnobotany: diversity indices', in Economic Botany, 50(3), 280-289.

Bell, R.H.V., 1984, Majete Game Reserve: Report of an Ulendo and suggestions for management and utilisation, Kasungu, Malawi.

Bond, W.J. \& van Wilgen, B.W., 1996, 'Fire and plants', London; Chapman and Hall.

Buchhorn, M. et al., 2019, 'Copernicus Global Land Service: Land Cover 100m: Epoch 2015: Globe', Version V2.0.2.

Burnham, K.P. \& Overton, W.S., 1978, 'Estimation of the size of a closed population when capture probabilities vary among animals', Biometrika, 65(3), 625-633.

Byers, B., 2001, Conserving the Miombo Ecoregion - Final Reconnaissance Summary Report, Reconnaissance Summary, WWF, Southern African Regional Programme Office (SARPO), Harare, Zimbabwe.

Chao, A., 2005, 'Species richness estimation', Encyclopaedia of statistical sciences, 12, 7907-7916.

Chirwa, P.W., Syampungani, S. \& Geldenhuys, C.J., 2014, 'Managing Southern African Woodlands for Biomass Production: The Potential Challenges and Opportunities', in K. von Gadow, T. Pullala, M. Tomé (eds), Managing Forest Ecosystems, pp. 137-167, Berlin: Springer.

Chiu, C.H. et al., 2014, 'An improved nonparametric lower bound of species richness via a modified good-turing frequency formula', Biometrics, 70(3), 671-682.

Clegg, B.W. \& Connor, T.M.O., 2012, 'The vegetation of Malilangwe Wildlife Reserve, south-eastern Zimbabwe', African Journal of Range \& Forage Science, 3, 109-131, https://doi.org/10.2989/10220119.2012.744352.

Colwell, R.K. 2005 'EstimateS: statistical estimation of species richness and shared species from samples. Version 7.5. User's guide and application', http://purl. oclc. org/estimates.

Colwell, R.K. \& Coddington, J.A., 1994, 'Estimating terrestrial biodiversity through extrapolation', Phil. Trans. R. Soc. Lond. B. The Royal Society, 345(1311), 101-118.

Conybeare, A.M., 2004, 'Elephant impacts on vegetation and other biodiversity in the broadleaved woodlands of S-Central Africa', Biodiversity of the Four Corners Area: Technical Reviews Volume Two. Biodiversity Foundation for Africa, Bulawayo/Zambezi Society, Harare, Zimbabwe, 477-508.

Dew, L.A. et al., 2017, 'Evaluating the efficacy of invasive plant control in response to ecological factors', South African Journal of Botany, 109, 203-213, https://doi. org/10.1016/j.sajb.2016.12.007.
Dowsett-Lemaire, F. \& Dowsett, R.J., 2002, Biodiversity surveys and the development of new research and monitoring strategies for the lower Shire protected areas, Lilongwe.

Duvane, J.A. et al., 2017, 'Characterization of the primary metabolome of Brachystegia boehmii and Colophospermum mopane under different fire regimes in miombo and mopane African woodlands', Frontiers in Plant Science, 8, 1-12, https://doi.org/10.3389/fpls.2017.02130.

Eastwood, R. \& Lipton, M., 2011, 'Demographic transition in sub-Saharan Africa: How big will the economic dividend be?', Population studies, 65(1), 9-35.

Edwards, E., 1983, 'A broad-scale structural classification of vegetation for practical purposes', Bothalia, 14(3/4), 705712, https://doi.org/10.4102/abc.v14i3/4.1231.

Enslin, B.W. et al., 2000, 'Long term effects of fire frequency and season on the woody vegetation dynamics of the Sclerocarya birrea/Acacia nigrescens savanna of the Kruger National Park', Koedoe, 43(1), 27-37, https://doi. org/10.4102/koedoe.v43i1.206.

FAO, 2015, Global Forest Resources Assessment 2015, Rome, Italy.

Frost, P., 1996, 'The Ecology of Miombo Woodlands', in B. Campbell (ed), The Miombo in Transition: Woodlands and Welfare in Africa, pp. 11-55, Bangor, Indonesia: $\mathrm{Cl}-$ FOR.

Furley, P.A. et al., 2008, 'Savanna burning and the assessment of long-term fire experiments with particular reference to Zimbabwe', Progress in Physical Geography, 32(6), 611634, https://doi.org/10.1177/0309133308101383.

Gandiwa, E. \& Kativu, S., 2009, 'Influence of fire frequency on Colophospermum mopane and Combretum apiculatum woodland structure and composition in Northern Gonarezhou National Park, Zimbabwe', Koedoe, 51(1), 1-13, https://doi.org/10.4102/koedoe.v51i1.685.

Geldenhuys, C.J. \& Golding, J. S., 2008, 'Resource use activities, conservation and management of natural resources of African savannas.', in F.G. Faleiro, N.A. Lopez (eds), Savannas: Challenges and Strategies for Equilibrium between Society and Agribusiness and Natural Resources, pp. 225-260, Brasilia, Brazil: Embrapa Cerrados.

Government of Malawi, 2010, Malawi state of environment and outlook report, Lilongwe, Malawi.

Goyder, D.J. et al., 2018, 'The Cuito catchment of the Okavango system: A vascular plant checklist for the Angolan headwaters', PhytoKeys, 31(113), 1-31, https://doi. org/10.3897/phytokeys.113.30439.

Hall-Martin, A.J., 1972, 'Aspects of the Plant Ecology of the Lengwe National Park, Malawi', University of Pretoria, South Africa. 
Hall-Martin, A.J. \& Drummond, R.B., 1980, 'Annotated list of plants collected in Lengwe National Park, Malawi', Kirkia, 151-181.

Heck Jr, K.L., van Belle, G. \& Simberloff, D., 1975, 'Explicit calculation of the rarefaction diversity measurement and the determination of sufficient sample size', Ecology, 56(6), 1459-1461.

Huntley, B.J., 1982, 'Southern African savannas', in Huntley, B.J. \& Walker, B.H. (eds) Ecology of tropical savannas, Berlin: Springer-Verlag, 101-119.

Jacobs, O.S. \& Biggs, R., 2001, 'The effect of different fire treatments on the population structure and density of the marula, Sclerocarya birrea (A.Rich.) subsp. caffra (Sond.) kokwaro (Kokwaro \& Gillet 1980) in the Kruger National Park', African Journal of Range and Forage Science, 18(1), 13-23, https://doi.org/10.2989/10220110109485750.

Jinga, P. \& Palagi, J., 2020, 'Dry and wet miombo woodlands of south-central Africa respond differently to climate change', Environmental Monitoring and Assessment, 192(6), 372, https://doi.org/10.1007/s10661-020-08342-x.

Kabwazi, H.H., Banda, A.K. \& Mwanyambo, M.L., 2000, 'Volume I: A Survey of Plant Resources in Protected Areas of the Lower Shire', Consultancy Report on Natural Resources Survey in Lengwe, Majete and Mwabvi, Malawi.

Kapinga, K. et al., 2018, 'Species-specific allometric models for estimation of the above-ground carbon stock in miombo woodlands of Copperbelt Province of Zambia', Forest Ecology and Management, 417, 184-196.

Kennedy, A.D. \& Potgieter, A.L.F., 2001, 'Fire season affects size and architecture of Colophospermum mopane in southern African savannas', Plant Ecology, 167, 179-192.

Kerr, J.T. \& Ostrovsky, M., 2003, 'From space to species: Ecological applications for remote sensing', Trends in Ecology and Evolution, 18(6), 299-305, https://doi.org/10.1016/ S0169-5347(03)00071-5.

Kremen, C., 1992, 'Assessing the Indicator Properties of Species Assemblages for Natural Areas Monitoring', Ecological Applications, 2(2), 203-217, https://doi.org/10.2307/1941776.

Kutsch, W.L. et al., 2011, 'The charcoal trap: Miombo forests and the energy needs of people', Carbon Balance and Management, 6, 1-11, https://doi.org/10.1186/17500680-6-5.

Luoga, E.J., Witkowski, E.T.F. \& Balkwill, K., 2004, 'Regeneration by coppicing (resprouting) of miombo (African savanna) trees in relation to land use', Forest Ecology and Management, 189(1-3), 23-35.

Malaisse, F. \& Parent, G., 1985, 'Edible wild vegetable products in the Zambezian woodland area: A nutritional and ecological approacht', Ecology of Food and Nutrition, 18(1), 43-82, https://doi.org/10.1080/03670244.1985.9990913.

Mapaure, I., 2001, 'Small-scale variations in species composition of miombo woodland in Sengwa, Zimbabwe: the influence of edaphic factors, fire and elephant herbivory', Systematics and geography of plants, 71(2), 935-947.

Maquia, I. et al., 2019, 'Diversification of African tree legumes in Miombo-Mopane woodlands', Plants, 8(6), 1-19, https://doi.org/10.3390/plants8060182.

van der Merwe, H. et al., 2019, 'Vachellia erioloba dynamics over 38 years in the Kalahari Gemsbok National Park, South Africa', Koedoe, 61(1), 1-12, https://doi.org/10.4102/koedoe.v61i1.1534.

Missanjo, E. et al., 2014, 'Evaluation of natural regeneration and tree species diversity in miombo woodlands in Malawi',
Journal of Biodiversity Management and Forestry, 3(3), pp. 1-4, https://doi.org/10.4172/2327-4417.1000127.

Mittermeier, R.A. et al., 2003, 'Wilderness and biodiversity conservation', PNAS, 100(18), 10309-10313.

Mohd Hasmadi, I., Pakhriazad, H.Z. \& Shahrin, M.F., 2009, 'Evaluating supervised and unsupervised techniques for land cover mapping using remote sensing data', Malaysian Journal of Society and Space, 5(1), 1-10.

Moura, I. et al., 2018, 'Woody species from the Mozambican Miombo woodlands: A review on their ethnomedicinal uses and pharmacological potential', Journal of Medicinal Plants Research, 12(2), 15-31, https://doi.org/10.5897/ jmpr2017.6540.

Munishi, P.K.T., Temu, R.P.C. \& Soka, G., 2011, 'Plant communities and tree species associations in a Miombo ecosystem in the Lake Rukwa basin, Southern Tanzania: Implications for conservation', Journal of Ecology and the Natural Environment, 3, 63-71.

Mwase, W.F. et al., 2007, 'The role of land tenure in conservation of tree and shrub species diversity in miombo woodlands of southern Malawi', New Forests, 33(3), 297307, https://doi.org/10.1007/s11056-006-9029-0.

Nefabas, L.L. \& Gambiza, J., 2007, 'Fire-tolerance mechanisms of common woody plant species in a semiarid savanna in south-western Zimbabwe', African Journal of Ecology, 45(4), 550-556, https://doi.org/10.1111/j.13652028.2007.00767.x.

Nieman, W.A., 2020, Integrated fire management plan: Majete Wildlife Reserve, Malawi, Technical Report 05/20, African Parks, Johannesburg, South Africa.

Nieman, W. A., Leslie, A. J.\& Wilkinson, A., 2019, 'Traditional medicinal animal use by Xhosa and Sotho communities in the Western Cape Province, South Africa', Journal of Ethnobiology and Ethnomedicine, 15(1), 34, https://doi. org/10.1186/s13002-019-0311-6.

Nieman, W.A., van Wilgen, B.W. \& Leslie, A.J., 2021, 'A reconstruction of the recent fire regimes of Majete Wildlife Reserve, Malawi, using remote sensing', Fire Ecology, 17(4), pp. 1-13, https://doi.org/10.1186/s42408-02000090-0.

Olivier, A., 2018 'Ecology of the black rhinoceros (Diceros bicornis minor) in Majete Wildlife Reserve, Malawi', University of Stellenbosch, South Africa.

Peel, M.J.S., Kruger, J.M. \& MacFadyen, S., 2007, 'Woody vegetation of a mosaic of protected areas adjacent to the Kruger National Park, South Africa', Journal of Vegetation Science, 18(6), 807-814, https://doi.org/10.1111/j.1654-1103.2007. tb02597.x.

Ribeiro, N.S., Shugart, H.H. \& Washington-Allen, R., 2008, 'The effects of fire and elephants on species composition and structure of the Niassa Reserve, northern Mozambique', Forest Ecology and Management, 255(5-6), 16261636.

van Rooyen, M.W. et al., 2008, 'Landscapes in the Kalahari Gemsbok National Park, South Africa', Koedoe, 50(1), 99-112.

Russell, J.M., Tedder, M.J. \& Demmer, S., 2019, 'Vachellia sieberiana var. woodii, a high-altitude encroacher: the effect of fire, frost, simulated grazing and altitude in north-western KwaZulu-Natal, South Africa', African Journal of Range and Forage Science, 36(4), 169-180, https://doi.org/10.29 89/10220119.2019.1667437. 
Ryan, C.M. \& Williams, M., 2011, 'How does fire intensity and frequency affect miombo woodland tree populations and biomass?', Ecological applications, 21(1), 48-60.

Satyanarayana, B. et al., 2011, 'Assessment of mangrove vegetation based on remote sensing and ground-truth measurements at Tumpat, Kelantan Delta, East Coast of Peninsular Malaysia', International Journal of Remote Sensing, 32(6), 1635-1650, https://doi.org/10.1080/01431160903586781.

Scholes, R.J. \& Walker, B.H., 1993, 'An African savanna: synthesis of the Nylsvley study', Cambridge University Press: Cambridge.

Sedano, F., Gong, P. \& Ferrão, M., 2005, 'Land cover assessment with MODIS imagery in southern African Miombo ecosystems', Remote Sensing of Environment, 98(4), 429441, https://doi.org/10.1016/j.rse.2005.08.009.

Shackleton, C.M. \& Scholes, R.J. 2000 'Impact of fire frequency on woody community structure and soil nutrients in the Kruger National Park', Koedoe, 43(1), 75-81, https://doi. org/10.4102/koedoe.v43i1.210.

Shannon, G. et al., 2011, 'Relative impacts of elephant and fire on large trees in a savanna ecosystem', Ecosystems, 14(8), 1372-1381.

Sherry, B.Y., 1989, 'Aspects of the ecology of the elephant Loxodonta africana (Blumenbach, 1797) in the middle Shire Valley, southern Malawi', University of Malawi.

Smit, I.P.J. et al., 2010, 'Effects of fire on woody vegetation structure in African savanna', Ecological Applications, 20(7), 1865-1875.

Smith, W., Meredith, T.C. \& Johns, T., 1999, 'Exploring methods for rapid assessment of woody vegetation in the Batemi Valley, North-central Tanzania', Biodiversity and Conservation, 8(4), 447-470, https://doi. org/10.1023/A:1008898331292.

Sweet, R.J., 1982, 'Bush control with fire in Acacia nigrescens/ Combretum apiculatum savanna in Botswana', Proceed- ings of the Annual Congresses of the Grassland Society of Southern Africa, 17(1), 25-28.

Syampungani, S. et al., 2009, 'The miombo woodlands at the cross roads: Potential threats, sustainable livelihoods, policy gaps and challenges', Natural Resources Forum, 33: 150-159.

Thomson, P.J., 1975, 'The role of elephants, fire and other agents in the decline of a Brachystegia boehmii woodland', Journal of the Southern African Wildlife Management Association, 5(1), 11-18.

Toti, D.S., Coyle, F.A. \& Miller, J.A., 2000, 'A structured inventory of Appalachian grass bald and heath bald spider assemblages and a test of species richness estimator performance', Journal of Arachnology, 28(3), 329-345.

Trapnell, C.G., 1959 'Ecological Results of Woodland Burning in Northern Rhodesia', Journal of Ecology, 47(1), 129-168.

Trollope, W.S.W., 1998, Effect and use of fire in the savanna areas of southern Africa. University of Fort Hare, South Africa.

Walters, M., Midgley, J.J. \& Somers, M.J., 2004, 'Effects of fire and fire intensity on the germination and establishment of Acacia karroo, Acacia nilotica, Acacia luederitzii and Dichrostachys cinerea in the field', Ecology, 4(3), 1-13, https://doi.org/10.1186/1472-6785-4-3.

White, F., 1983, The vegetation of Africa. Paris: UNESCO.

van Wilgen, B.W. et al., 2014, 'The ongoing development of a pragmatic and adaptive fire management policy in a large African savanna protected area', Journal of Environmental Management 132, 358-368, https://doi.org/10.1016/j.jenvman.2013.11.003.

Williams, V.L., Witkowski, E.T.F. \& Balkwill, K., 2007, 'The use of incidence-based species richness estimators, species accumulation curves and similarity measures to appraise ethnobotanical inventories from South Africa', Biodiversity and Conservation, 16(9), 2495-2513. 


\section{Supplementary Material}

Table S1. List of tree and shrub species found in Majete Wildlife Reserve in this study, as well as the number of transects and the woody plant communities in which species occurred. The woody plant communities are: $\mathrm{Rw}=$ Riparian woodland, $\mathrm{Gr}=\mathrm{Grassland}, \mathrm{SW}=$ Shrublands and woodlands, Tw = Transitional woodland, and $\mathrm{M}=$ Miombo.

\begin{tabular}{|c|c|c|c|}
\hline Family & Species & $\begin{array}{c}\text { Number of } \\
\text { transects present }\end{array}$ & $\begin{array}{l}\text { Vegetation types } \\
\text { present }\end{array}$ \\
\hline \multirow[t]{3}{*}{ Arecaceae [the palm family] } & Hyphaene coriacea (lala palm) & $4(4.26 \%)$ & Rw and SW \\
\hline & Hyphaene petersiana (vegetable ivory palm) & $3(3.19 \%)$ & SW \\
\hline & Phoenix reclinata (wild date palm) & $2(2.13 \%)$ & SW and Tw \\
\hline $\begin{array}{l}\text { Boraginaceae [the borage or } \\
\text { forget-me-not family] }\end{array}$ & Ehretia amoena (sandpaper stamperwood) & $6(6.38 \%)$ & Rw, SW and Tw \\
\hline \multirow{2}{*}{$\begin{array}{l}\text { Capparaceae [the Caper } \\
\text { family] }\end{array}$} & Boscia salicifolia (willow-leaved Boscia) & $3(3.19 \%)$ & Rw and Tw \\
\hline & Cadaba kirkii (wormbush) & $1(1.06 \%)$ & SW \\
\hline \multirow{2}{*}{$\begin{array}{l}\text { Celastraceae [the staff wine or } \\
\text { bittersweet family] }\end{array}$} & Gymnosporia senegalensis (confetti tree) & $6(6.38 \%)$ & Rw and Tw \\
\hline & Pleurostylia capensis (coffee pear) & $1(1.06 \%)$ & M \\
\hline \multirow[t]{4}{*}{ Ebenaceae [the ebony family] } & Diospyros kirkii (large-leaved jackalberry) & $26(27.66 \%)$ & Rw, SW, Tw and M \\
\hline & Diospyros mespiliformis (jackalberry) & $39(41.49 \%)$ & SW, Tw and $M$ \\
\hline & Diospyros squarrosa (rigid star-berry) & $6(6.38 \%)$ & Rw and SW \\
\hline & Diospyros usambarensis (sand star-apple) & $2(2.13 \%)$ & SW \\
\hline \multirow{20}{*}{$\begin{array}{l}\text { Fabaceae [the legume, pea or } \\
\text { bean family] }\end{array}$} & Afzelia quanzensis (pod mahogany) & $2(2.13 \%)$ & SW \\
\hline & Albizia harveyi (bushveld Albizia) & $4(4.26 \%)$ & SW and Tw \\
\hline & Bauhinia petersiana (Zambezi coffee) & $3(3.19 \%)$ & SW and Tw \\
\hline & Bolusanthus speciosus (tree wisteria) & $2(2.13 \%)$ & SW and Tw \\
\hline & Brachystegia allenii (escarpment Brachystegia) & $1(1.06 \%)$ & $\mathrm{Tw}$ \\
\hline & Brachystegia boehmii (Prince of Wales feathers) & $5(5.32 \%)$ & Tw and $M$ \\
\hline & Brachystegia longifolia (mubombo) & $29(30.85 \%)$ & Rw, SW, Tw and M \\
\hline & Brachystegia spiciformis (zebrawood) & $7(7.45 \%)$ & Rw, Tw and $M$ \\
\hline & Brachystegia utilis (false mafuti) & $21(22.34 \%)$ & SW, Tw and $M$ \\
\hline & Burkea africana (wild seringa) & $1(1.06 \%)$ & SW \\
\hline & Cassia abbreviata (sjambok pod) & $6(6.38 \%)$ & SW and Tw \\
\hline & Colophospermum mopane (mopane) & $26(27.66 \%)$ & SW, Tw and M \\
\hline & Cordyla africana (wild mango) & $4(4.26 \%)$ & Rw and SW \\
\hline & Craibia brevicaudata (mountain ironwood) & $1(1.06 \%)$ & $\mathrm{Tw}$ \\
\hline & $\begin{array}{l}\text { Dalbergia arbutifolia (eastern climbing } \\
\text { Dalbergia) }\end{array}$ & $2(2.13 \%)$ & $\mathrm{Rw}$ \\
\hline & Dalbergia boehmii (large-leaved Dalbergia) & $3(3.19 \%)$ & SW and $M$ \\
\hline & Dalbergia melanoxylon (African blackwood) & $10(10.64 \%)$ & Rw, SW, Tw and M \\
\hline & Dalbergia obovata (climbing flat-bean) & $4(4.26 \%)$ & SW and Tw \\
\hline & Dichrostachys cinerea (sicklebush) & $5(5.32 \%)$ & Rw, SW and Tw \\
\hline & Erythrophleum africanum (ordeal tree) & $6(6.38 \%)$ & SW and $M$ \\
\hline
\end{tabular}


Table S1. List of tree and shrub species found in Majete Wildlife Reserve in this study, as well as the number of transects and the woody plant communities in which species occurred. The woody plant communities are: Rw = Riparian woodland, Gr = Grassland, SW = Shrublands and woodlands, Tw = Transitional woodland, and $\mathrm{M}=$ Miombo (continued).

\begin{tabular}{|c|c|c|c|}
\hline Family & Species & $\begin{array}{l}\text { Number of } \\
\text { transects present }\end{array}$ & $\begin{array}{l}\text { Vegetation types } \\
\text { present }\end{array}$ \\
\hline \multirow{17}{*}{$\begin{array}{l}\text { Fabaceae [the legume, pea or } \\
\text { bean family] (continued) }\end{array}$} & Julbernardia globiflora (munondo) & $6(6.38 \%)$ & SW, Tw and $M$ \\
\hline & Mundulea sericea (cork bush) & $5(5.32 \%)$ & SW and Tw \\
\hline & Ormocarpum kirkii (caterpillar bush) & $7(7.45 \%)$ & SW, Tw and $M$ \\
\hline & Philenoptera bussei (small apple-leaf) & $2(2.13 \%)$ & SW and $M$ \\
\hline & Philenoptera violacea (apple-leaf) & $20(21.28 \%)$ & Rw, SW, Tw and M \\
\hline & Piliostigma thonningii (camel's foot) & $2(2.13 \%)$ & SW and $M$ \\
\hline & Pterocarpus lucens (small-leaved bloodwood) & $2(2.13 \%)$ & SW and $M$ \\
\hline & $\begin{array}{l}\text { Pterocarpus rotundifolius (round-leaved } \\
\text { bloodwood) }\end{array}$ & $16(17.02 \%)$ & Rw, SW and Tw \\
\hline & Senegalia burkei (black monkey thorn) & $5(5.32 \%)$ & SW, Tw and $M$ \\
\hline & Senegalia galpinii (monkey thorn) & $6(6.38 \%)$ & SW, Tw and $M$ \\
\hline & Senegalia nigrescens (knob-thorn) & $41(43.62 \%)$ & Rw, SW, Tw and $M$ \\
\hline & Tamarindus indica (tamarind) & $5(5.32 \%)$ & SW and Tw \\
\hline & Tephrosia aequilata (common name unknown) & $1(1.06 \%)$ & SW \\
\hline & Vachellia karroo (sweet thorn) & $1(1.06 \%)$ & SW \\
\hline & Vachellia nilotica (gum arabic tree) & $23(24.47 \%)$ & Rw, SW, Tw and M \\
\hline & Vachellia torrei (Mozambique sticky thorn) & $14(14.89 \%)$ & Rw, SW, Tw and M \\
\hline & Xeroderris stuhlmannii (wing pod) & $11(11.70 \%)$ & Rw, SW, Tw and $\mathrm{M}$ \\
\hline \multirow{2}{*}{$\begin{array}{l}\text { Apocynaceae [the dogbane } \\
\text { family] }\end{array}$} & Diplorhynchus condylocarpon (horn-pod tree) & $34(36.17 \%)$ & SW, Tw and $M$ \\
\hline & Holarrhena pubescens (fever-pod) & $11(11.70 \%)$ & Rw, SW, Tw and $M$ \\
\hline \multirow{5}{*}{$\begin{array}{l}\text { Rubiaceae [the coffee, } \\
\text { madder or bedstraw family] }\end{array}$} & Catunaregam obovata (coastal bone-apple) & $4(4.26 \%)$ & SW and Tw \\
\hline & Cremaspora trifloral (cremaspora) & $7(7.45 \%)$ & Rw, SW and Tw \\
\hline & Crossopteryx febrifuga (common crown-berry) & $1(1.06 \%)$ & SW \\
\hline & Gardenia volkensii (bushveld gardenia) & $1(1.06 \%)$ & $\mathrm{Tw}$ \\
\hline & Pavetta schumanniana (poison pavetta) & $2(2.13 \%)$ & SW \\
\hline \multirow{4}{*}{$\begin{array}{l}\text { Bignoniaceae [the jacaranda } \\
\text { family] }\end{array}$} & Kigelia africana (sausage tree) & $9(9.57 \%)$ & Rw, SW and $M$ \\
\hline & Markhamia acuminate (bean-tree) & $4(4.26 \%)$ & Rw, SW and $M$ \\
\hline & Stereospermum kunthianum (pink jacaranda) & $1(1.06 \%)$ & M \\
\hline & Tecoma nyassae (Cape honeysuckle) & $1(1.06 \%)$ & SW \\
\hline $\begin{array}{l}\text { Lamiaceae [the mint, } \\
\text { deadnettle or sage family] }\end{array}$ & Karomia tettensis (northern Chinese-hats) & $1(1.06 \%)$ & SW \\
\hline $\begin{array}{l}\text { Verbenaceae [the verbena } \\
\text { family] }\end{array}$ & Lantana camara (West Indian lantana) & $2(2.13 \%)$ & $\mathrm{Rw}$ \\
\hline \multirow{2}{*}{$\begin{array}{l}\text { Annonaceae [the custard } \\
\text { apple family] }\end{array}$} & Friesodielsia obovata (northern dwaba-berry) & $2(2.13 \%)$ & Rw \\
\hline & Monanthotaxis caffra (dwaba-berry) & $1(1.06 \%)$ & SW \\
\hline $\begin{array}{l}\text { Clusiaceae [the St John's wort } \\
\text { family] }\end{array}$ & Garcinia livingstonei (African mangosteen) & $1(1.06 \%)$ & SW \\
\hline \multirow{2}{*}{$\begin{array}{l}\text { Euphorbiaceae [the euphorbia } \\
\text { family] }\end{array}$} & Croton megalobotrys (fever-berry) & $5(5.32 \%)$ & Rw and SW \\
\hline & Croton sylvaticus (forest croton) & $2(2.13 \%)$ & SW \\
\hline
\end{tabular}


Table S1. List of tree and shrub species found in Majete Wildlife Reserve in this study, as well as the number of transects and the woody plant communities in which species occurred. The woody plant communities are: Rw = Riparian woodland, Gr = Grassland, SW = Shrublands and woodlands, Tw = Transitional woodland, and $\mathrm{M}=$ Miombo (continued).

\begin{tabular}{|c|c|c|c|}
\hline Family & Species & $\begin{array}{l}\text { Number of } \\
\text { transects present }\end{array}$ & $\begin{array}{c}\text { Vegetation types } \\
\text { present }\end{array}$ \\
\hline Ochnaceae [the ochna family] & Ochna mossambicensis (large-flowered ochna) & $1(1.06 \%)$ & SW \\
\hline \multirow[t]{8}{*}{ Phyllanthaceae } & Bridelia cathartica (blue sweetberry) & $5(5.32 \%)$ & SW and Tw \\
\hline & Cleistanthus schlechteri (muti-usina-zita) & $1(1.06 \%)$ & SW \\
\hline & Cleistochlamys kirkii (purple cluster-pear) & $11(11.70 \%)$ & Rw, SW, Tw and M \\
\hline & Flueggea virosa (snowberry tree) & $2(2.13 \%)$ & SW \\
\hline & Hymenocardia acida (large red-heart) & $1(1.06 \%)$ & Tw \\
\hline & Phyllanthus reticulatus (potato plant) & $1(1.06 \%)$ & SW \\
\hline & $\begin{array}{l}\text { Pseudolachnostylis maprouneifolia (duiker- } \\
\text { berry) }\end{array}$ & $10(10.64 \%)$ & SW, Tw and M \\
\hline & Uapaca sansibarica (lesser mahobohobo) & $1(1.06 \%)$ & M \\
\hline Salicaceae [the willow family] & Flacourtia indica (governor's plum) & $4(4.26 \%)$ & Tw and $M$ \\
\hline $\begin{array}{l}\text { Dipterocarpaceae [the } \\
\text { meranti family] }\end{array}$ & Monotes africanus (Muwase) & $4(4.26 \%)$ & SW and Tw \\
\hline \multirow[t]{7}{*}{ Malvaceae [the mallow family] } & Adansonia digitata (African baobab) & $5(5.32 \%)$ & Rw and SW \\
\hline & Grewia bicolor (white-leaved raisin) & $5(5.32 \%)$ & Rw and SW \\
\hline & Grewia flavescens (sandpaper raisin) & $5(5.32 \%)$ & Rw and SW \\
\hline & Grewia forbesii (worty donkey-berry) & $7(7.45 \%)$ & SW and Tw \\
\hline & Sterculia africana (African star-chestnut) & $11(11.70 \%)$ & Rw, SW, Tw and $M$ \\
\hline & $\begin{array}{l}\text { Sterculia quinqueloba (large-leaved star- } \\
\text { chestnut) }\end{array}$ & $3(3.19 \%)$ & Rw and SW \\
\hline & Sterculia rogersii (small-leaved star-chestnut) & $2(2.13 \%)$ & SW and Tw \\
\hline $\begin{array}{l}\text { Meliaceae [the mahogany } \\
\text { family] }\end{array}$ & Trichilia emetica (Natal mahogany) & $3(3.19 \%)$ & Rw and SW \\
\hline \multirow[t]{10}{*}{$\begin{array}{l}\text { Combretaceae [the } \\
\text { combretum family] }\end{array}$} & $\begin{array}{l}\text { Combretum adenogonium (four-leaved } \\
\text { bushwillow) }\end{array}$ & $51(54.26 \%)$ & Rw, SW, Tw and M \\
\hline & Combretum apiculatum (red bushwillow) & $28(29.79 \%)$ & SW, Tw and M \\
\hline & Combretum hereroense (russet bushwillow) & $15(15.96 \%)$ & SW, Tw and $M$ \\
\hline & Combretum imberbe (leadwood) & $34(36.17 \%)$ & Rw, SW and Tw \\
\hline & Combretum molle (velvet bushwillow) & $21(22.34 \%)$ & Rw, SW, Tw and M \\
\hline & $\begin{array}{l}\text { Combretum mossambicense (knobbly } \\
\text { bushwillow) }\end{array}$ & $2(2.13 \%)$ & SW \\
\hline & Combretum zeyheri (large-fruited bushwillow) & $22(23.40 \%)$ & Rw, SW, Tw and M \\
\hline & Terminalia mollis (large-leaved terminalia) & $4(4.26 \%)$ & SW, Tw and $M$ \\
\hline & Terminalia sericea (silver cluster-leaf) & $33(35.11 \%)$ & Rw, SW, Tw and $M$ \\
\hline & $\begin{array}{l}\text { Terminalia stenostachya (rosette-leaved } \\
\text { terminalia) }\end{array}$ & $3(3.19 \%)$ & SW, Tw and $M$ \\
\hline $\begin{array}{l}\text { Myrtaceae [the eucalyptus } \\
\text { family] }\end{array}$ & Eucalyptus camaldulensis (river red gum) & $1(1.06 \%)$ & SW \\
\hline Proteaceae [the protea family] & Faurea rochetiana (broad-leaved beechwood) & $4(4.26 \%)$ & SW and Tw \\
\hline
\end{tabular}


Table S1. List of tree and shrub species found in Majete Wildlife Reserve in this study, as well as the number of transects and the woody plant communities in which species occurred. The woody plant communities are: Rw = Riparian woodland, Gr = Grassland, SW = Shrublands and woodlands, Tw = Transitional woodland, and $\mathrm{M}=$ Miombo (continued).

\begin{tabular}{|c|c|c|c|}
\hline Family & Species & $\begin{array}{l}\text { Number of } \\
\text { transects present }\end{array}$ & $\begin{array}{c}\text { Vegetation types } \\
\text { present }\end{array}$ \\
\hline \multirow{3}{*}{$\begin{array}{l}\text { Moraceae [the fig or mulberry } \\
\text { family] }\end{array}$} & Ficus abutilifolia (large-leaved rock fig) & $1(1.06 \%)$ & SW \\
\hline & Ficus sycamorus (sycamore fig) & $2(2.13 \%)$ & Rw \\
\hline & Maclura africana (thorny mulberry) & $2(2.13 \%)$ & Rw \\
\hline \multirow{2}{*}{$\begin{array}{l}\text { Rhamnaceae [the buffalo- } \\
\text { thorn family] }\end{array}$} & Berchemia discolor (brown ivory) & $1(1.06 \%)$ & $\mathrm{Tw}$ \\
\hline & Ziziphus mucronata (buffalo-thorn) & $3(3.19 \%)$ & Rw and SW \\
\hline \multirow{3}{*}{$\begin{array}{l}\text { Olacaceae [the sour plum } \\
\text { family] }\end{array}$} & Ximenia americana (tallow wood) & $2(2.13 \%)$ & Tw and $M$ \\
\hline & Ximenia caffra (large sourplum) & $4(4.26 \%)$ & SW and Tw \\
\hline & Jasminum fluminense (Brazilian jasmine) & $1(1.06 \%)$ & SW \\
\hline \multirow{3}{*}{$\begin{array}{l}\text { Anacardiaceae [the cashew or } \\
\text { sumac family] }\end{array}$} & Lannea stuhlmannii (false marula) & $3(3.19 \%)$ & Rw and Tw \\
\hline & Ozoroa reticulata (raisin bush) & $1(1.06 \%)$ & $\mathrm{Tw}$ \\
\hline & Sclerocarya birrea (marula) & $29(30.85 \%)$ & Rw, SW, Tw and M \\
\hline \multirow{3}{*}{$\begin{array}{l}\text { Burseraceae [the torchwood } \\
\text { or myrrh family] }\end{array}$} & Commiphora africana (poison-grub corkwood) & $2(2.13 \%)$ & SW and $M$ \\
\hline & Commiphora mollis (velvet-leaved corkwood) & $1(1.06 \%)$ & SW \\
\hline & $\begin{array}{l}\text { Commiphora mossambicensis (pepper-leaved } \\
\text { corkwood) }\end{array}$ & $1(1.06 \%)$ & SW \\
\hline \multirow[t]{2}{*}{ Kirkiaceae [the kirkia family] } & Kirkia acuminata (white seringa) & $3(3.19 \%)$ & SW \\
\hline & Kirkia wilmsii (wild pepper tree) & $1(1.06 \%)$ & SW \\
\hline \multirow{4}{*}{$\begin{array}{l}\text { Sapindaceae [the soapberry } \\
\text { family] }\end{array}$} & Allophylus africanus (African false-current) & $9(9.57 \%)$ & Rw and SW \\
\hline & Dodonaea viscosa (sticky hop-bush) & $2(2.13 \%)$ & SW and Tw \\
\hline & Zanha africana (velvet-fruited zanha) & $1(1.06 \%)$ & M \\
\hline & Zanha golungensis (smooth-fruit zanha) & $1(1.06 \%)$ & Tw \\
\hline
\end{tabular}

